\title{
PENGEMBANGAN MEDIA PEMBELAJARAN BERBASIS CAMTASIA STUDIO VIDEO CD INTERAKTIF MULTIMEDIA UNTUK MATA PELAJARAN PEMROGRAMAN WEB DI JURUSAN MULTIMEDIA SMK NEGERI 3 SINGARAJA
}

\author{
M. Iskandar Putra1, K. Udy Ariawan2, I W. Sutaya3 \\ ${ }^{1}$ Prodi Pendidikan Teknik Elektro,Universitas Pendidikan Ganesha, Singaraja \\ ${ }^{2,3}$ Prodi Teknik Elektronika,Universitas Pendidikan Ganesha, Singaraja \\ e-mail : putraiskandar877@gmail.com, udyariawan@gmail.com, sutaya.elkt@gmail.com³
}

\begin{abstract}
Abstrak
Mata pelajaran pemrograman web merupakan mata pelajaran yang mutlak terdapat di jurusan multimedia pembahasan mata pelajaran pemrograman web mengenai bagaimana cara membuat html. Di dalam mata pelajaran pemrograman web terdapat beberapa masalah yaitu siswa di kelas kurang untuk mengapikasikan materi yang telah di sampaikan dalam pembuatan html web Penelitian ini bertujuan membuat media pembelajaran video CD Intraktif multimedia dengan mengunakan software camtasia pada mata pelajaran pemrograman web. pembelajaran yang dapat ditinjau dari segi segi materi, media, design, serta bahasa. Penelitian ini dilakukan dengan menggunakan metode Research and Development dalam bidang pendidikan. video CD Intraktif multimedia yang dikembangkan sesuai dengan mata pelajaran yang berada di Jurusan Multimedia yaitu Pemrograman Web. Tampilan video CD Intraktif multimedia dibuat semacam tutorial menampilkan cara pembuatan html web serta didalam materi yang dikembangkan terdapat konten multimedia berupa gambar, animasi dan efek sebagai pendukung interaktifnya video CD Intraktif multimedia yang dikembangkan. Hasil dari uji validasi terhadap validator ahli pada mata pelajaran pemrograman web dan guru pemgempu mata pelajaran pemrograman web di smk $\mathrm{n} 3$ singaraja sesuai dengan indikator materi dari silabus.
\end{abstract}

Kata Kunci: video cd interaktif multimedia, pemrograman web

\begin{abstract}
Web programming subjects are subjects that are contained in the majors absolute multimedia web programming subjects of discussion about how to create html. In the subjects of web programming, there are several problems that students in the classroom less for mengapikasikan material that has been conveyed in making web html This research aims to make learning media video multimedia CD Intraktif by using Camtasia software on the subjects of web programming. learning can be evaluated in terms of in terms of material, media, design, and language. This research was conducted by the Research and Development in the field of education. Intraktif CD video multimedia are developed in accordance with the subjects that are in the Department of Multimedia ie Web Programming. Multimedia video display CD Intraktif created a sort of tutorial to show you how making htm/ web as well as in the materials developed are multimedia content such as images, animation and video effects to support interactive multimedia $C D$ Intraktif developed. The results of the validation test against validator expert on the subjects of web programming and teachers pemgempu web programming subjects in smk $n 3$ singaraja according to indicators of material from the silabus.
\end{abstract}

Keywords: video cd interaktif multimedia, pemrograman web

\section{Pendahuluan}

Pendidikan merupakan sala satu bidang yang terus berkembang seiring dengan perkembangan ilmu pengetahuan dan teknologi (iptek). Oleh karena itu pembaharuan pada bidang pedidikan sangat penting untuk dilakukan. Upaya pembaharuan yang dapat dilakukan salah satunya adalah penyelenggaraan pendidikan ada semua jenjang dan jenis pendidikan harus mampu mencapai tujuan pendidikan yang diharapkan. Sehingga sumber daya manusia yang dihasilkan dapat menghadapi perkembangan yang terjadi karena sumber daya manusia adalah salah satu aspek yang sangat besar perannya dalam kemajuan suatu bangsa. Semakin berkualitas sumber daya manusia yang dimiliki, maka semakin maju bangsa tersebut. 
Media pembelajaran merupakan salah faktor penting dalam peningkatan kualitas pembelajaran. Hal tersebut disebabkan adanya perkembangan teknologi dalam bidang pendidikan yang menuntut efisiensi dan efektivitas dalam pembelajaran. Untuk mencapai tingkat efisiensi dan efektivitas yang optimal, salah satu upaya yang perlu dilakukan adalah mengurangi bahkan jika perlu menghilangkan dominasi sistem penyampaian pelajaran yang bersifat verbalistik dengan cara menggunakan media pembelajaran. Sehubungan dengan penggunaan media dalam kegiatan pembelajaran, para tenaga pengajar atau guru perlu cermat dalam pemilihan dan atau penetapan media yang akan digunakannya. Kecermatan dan ketepatan dalam pemilihan media akan menunjang efektivitas kegiatan pembelajaran yang dilakukannya. Disamping itu juga kegiatan pembelajaran menjadi menarik sehingga dapat menimbulkan motivasi belajar, dan perhatian siswa menjadi terpusat kepada topik yang dibahas dalam kegiatan pembelajaran yang dilakukannya.Kecermatan dan ketepatan dalam memilih media pembelajaran dipengaruhi oleh banyak faktor seperti luas sempitnya pengetahuan dan pemahaman tenaga pengajar tentag kriteria dan faktor-faktor yang perlu dipertimbangkan serta prosedur pemilihan media pembelajaran. Uraian berikut akan membahas hal-hal dimaksud agar kita dalam memilihan media pembelajaran lebih tepat.

Dan media pembelajaran dapat dikatakan sebagai semua alat yang dapat digunakan sebagai media dalam pembelajaran. Secara terminologis, terdapat berbagai definisi yang diberikan tentang media pembelajaran. Media pembelajaran menurut Gerlach dan Ely (dalam Asyhar, 2012:7), memiliki cakupan yang sangat luas, yaitu termasuk manusia, materi, atau kajian yang membangun suatu kondisi yang membuat peserta didik mampu memperoleh pengetahuan, keterampilan, atau sikap. Pendapat Schramm (dalam Asyhar, 2012:7) tentang media pembelajaran adalah teknologi pembawa pesan (informasi) yang dapat dimanfaatkan untuk keperluan pembelajaran.

Sesuai dengan karakteristik media pembelajaran dibagi menjadi empat jenis, yaitu media audio, media visual, media audio visual, dan multimedia. Media pembelajaran yang digunakan tidak hanya berupa audio maupun visual, namun telah berbentuk audio visual. Seiring berkembangnya teknologi, media pembelajaran kian berkembang. Semua jenis media, dari media audio, media visual, maupun media audio visual kini dapat digunakan dalam satu media yakni multimedia. Multimedia merupakan penggabungan dari dua kata yaitu "multi" dan "media". Multi berarti banyak sedangkan media merupakan bentuk jamak dari medium yang berarti perantara. Istilah multimedia digunakan untuk menyatukaan teknologi digital dan analog di bidang entertainment, publishing, communication, marketing, advertising, dan juga commercial (Asyhar, 2012:75). Dari berbagai macam media yang dapat digunakan sebagai media pembelajaran, salah satunya berupa media berbasis komputer untuk menyajikan materi pelajaran sebagai media interaktif. Peranan -peranan media pembelajaran video cd interaktif multimedia sangatlah penting dalam proses transformasi ilmu pengetahunan itu sendiri, karena media pembelajaran video cd interaktif multimedia ini sangat penting untuk diperadakan dimana media pelajaran pemrograman web diperuntukkan untuk memotivasi siswa, memberikan pengalaman serta mempermudah siswa dalam mencerna dan memahami bagaimana cara membuat html web .

Dengan kemajuan teknologi, perpaduan komputer dan kepingan CD dapat digunakan sebagai media pembelajaran yang efektif dan efisien dalam bentuk CD pembelajaran interaktif. Apalagi di hampir setiap sekolah sudah mempunyai komputer yang jumlahnya cukup memadai untuk digunakan dalam proses pembelajaran serta siswa yang mempunyai keterampilan memadai juga untuk mengoperasikan komputer. pembelajaran video cd interaktif multimedia merupakan sebuah media yang menegaskan sebuah format multimedia dapat dikemas dalam sebuah CD (Compact Disk) dengan tujuan aplikasi interaktif di dalamnya. CD ROM (Read Only Memory) merupakan satu-satunya dari beberapa kemungkinan yang dapat menyatukan suara, video, teks, dan program dalam CD.

Dimana paradigma belajar di sekolah diarahkan lebih banyak pada siswa sebagai subyek pembelajaran dan guru hanya bertindak sebagai fasilitator. Salah satu buku ajar adalah buku sekolah elektronik (BSE). Namun, dalam penggunaannya di berbagai sekolah memiliki kelemahan yang patut disempurnakan dengan menampilkan simulasi dengan memadukan video, audio, dan gambar yang dikemas ke dalam video cd interaktif multimedia Keuntungan 
video cd interaktif multimedia dapat digunakan dimana saja, kapan saja. Pembaca dapat mengakses video cd interaktif multimedia dengan tinggal measukan CD ke dalam pc maupun leptop.

Pengaksesan video cd interaktif multimedia yang menampilkan sebuah video dengan tahap-tahp pembuatan html web secara garis besar hampir sama dengan tutorial video, tapi untuk video cd interaktif multimedia materi-materi yang terdapat di dalamnya tersusun dengan benar dikarenakan video cd interaktif multimedia mngunakan buku sekolah elektronik (BSE) sebagai pedoman.

Jurusan Multimedia di SMK Negeri 3 Singaraja memiliki kurang lebih sepuluh mata pelajaran yang diajarkan. Sepuluh mata pelajaran tersebut adalah Tenik Animasi 3 Dimensi, Teknik Animasi 2 Dimensi, Desain Multimedia, Pengolahan Citra Digital, Komposisi Foto Digital, Pengambilan Gambar Bergerak, Teknik Pengolahan Audio, Teknik Pengolahan Video, Desain Multimedia Interaktif, dan Kerja Proyek. Banyaknya mata pelajaran yang dipelajari oleh peserta didik membuat peserta didik sulit untuk memahami materi yang diberikan serta tidak semua peserta didik mampu menguasai materi. Terlebih lagi materi yang diberikan hanya berlangsung ketika jam belajar mengajar berlangsung serta buku penunjang yang digunakan oleh peserta didik sangat minim, sehingga peserta didik tidak mampu mengasah pengetahuan dan pemahaman mengenai mata pelajaran yang diajarkan diluar proses kegiatan belajar mengajar.

Berdasarkan uraian diatas, maka perlu dikembangkan sebuah media pembelajaran interaktif sebagai pegangan atau referensi peserta didik dalam Jurusan Multimedia. Peserta didik dapat menggunakan media pembelajaran ini dimana saja, dan kapan saja sehingga dapat mengasah pengetahuan dan pemahaman mereka dalam Jurusan Multimedia serta dapat mendukung sistem pembelajaran yang telah ada. Oleh sebab itu, peneliti akan mengembangkan media pembelajaran berupa video cd interaktif multimedia dengan memadukan konten multimedia didalamnya yang dapat digunakan sebagai alternatif dalam proses kegiatan belajar mengajar pada mata pelajaran pada Jurusan Multimedia khususnya pada mata pelajaran Pemrograman Web di SMK Negeri 3 Singaraja.

Berdasarkan latar belakang di atas maka muncul permasalahan sebagai berikut.bagaimana mengembangkan media pembelajaran berbasis camtasia studio video cd interaktif multimedia untuk pelajaran Pemrograman Dari rumusan yang dikemukan di atas adapun tujuan dari penelitian ini adalah sebagai berikut untuk membuat dan mengembangkan sofeware/aplikasi camtasia berupa video CD interaktif untuk membantu dan mempermudah pembelajaran Mata pelajaran Pemrograman Web di Jurusan Multimedia SMK Negeri 3 Singaraja

Manfaat dari hasil penelitian ini adalah Memberikan sumbangan pemikiran berupa pengembangan media pembelajaran dalam rangka meningkatkan kualitas pendidikan, dapat mempermudah memahami tentang pemrograman web, mampu mengaplikasikan Pengunaan pemrograman web, Sebagai media pembelajaran pemrograman web, untuk membantu menyampaikan materi, menambah wawasan, pengetahuan, serta keterampilan peneliti dalam pengembangan media pembelajaran.

Dalam penelitian ini peneliti membatasi pada masalah yang mencangkup ,mata pelajaran yang dijadikan video cd interaktif multimedia yakni mata pelajaran pemrograman web dan pembahasanya tentang html, sampel yang akan diteliti terletak di smk negeri 3 singaraja pada kelas XI jurusan multimedia. materi yang di jelaskan di video cd interaktif multimedia hanya terdiri dari 5 bab, pengaksean video cd interaktif multimedia berupa pc.

Media pembelajaran berasal dari bahasa latin dan merupakan bentuk jamak dari kata medium yang secara harfiah berarti perantara atau pengantar. Sedangkan Menurut Asosiasi Pendidikan Nasional menyatakan media adalah bentuk-bentuk komunikasi baik tercetak maupun audiovisual serta peralatannya. Dimana media hedaknya dapat memanipulasi, dapat dilihat, didengar dan dibaca (Arief S Sadiman. Dkk, 2006:7). Brigg berpendapat bahwa media adalah segala alat fisik yang dapat menyajikan pesan serta merangsang siswa untuk belajar (Arief S Sadiman. Dkk, 2006:7). (dalam Asyhar, 2012:4) menyatakan bahwa media adalah apa saja yang digunakan untuk menyalurkan informasi. Menurut Suparman (dalam Asyhar, 2012:4), media merupakan alat yang digunakan untuk menyalurkan pesan dan informasi dari pengirim 
pesan kepada penerima pesan. Media merupakan salah satu komponen komunikasi, yaitu sebagai pembawa pesan dari komunikator menuju komunikan (Criticos, 1996) dalam Santyasa, (2007). Gerlach \& Ely (dalam Arsyad, 2005) mengatakan bahwa media apabila dipahami secara garis besar adalah manusia, materi, atau kejadian yang membangun kondisi yang membuat siswa mampu memperoleh pengetahuan, keterampilan, atau sikap. Heinich, dan kawan-kawan (dalam Arsyad, 2005) mengemukakan istilah medium sebagai perantara yang mengantarkan informasi antara sumber dan penerima. Media memiliki peran yang sangat penting, yaitu suatu sarana atau perangkat yang berfungsi sebagai perantara atau saluran dalam suatu proses komunikasi antara komunikator dengan komunikan (Asyhar, 2012:5).

Video cd Intraktif multimedia atau disebut media pembelajaran cd interaktif berbasis video yang membutuhkan personal computers. Dalam video cd interaktif mutimedia ini adalah inovasi sebuah media yang menampilkan cara atau langkah-langkah pembuatan html web yang dapat mempermudah siswa untuk memahami dan mengaplikasikan, kemudian dapat merangsang siswa lebih aktif disisi lain siswa tidak perlu lagi sulit untuk membaca buku tingal mengikuti langkah cara pembuatan html web dengan media video cd Intraktif multimedia. Rayandra Asyhar (2012:74) berpendapat "video merupakan rekaman gambar dan suara dalam kaset pita video kedalam vita magnetik. Media Video dirancang untuk menghasilkan gambar yang realistis dunia sekitar kita". Menurut Sudatha \& Tegeh (2009) keuntungan menggunakan video adalah dapat menunjukan situasi yang nyata kepada siswa sehingga siswa dapat melihat gambar terbaik.

Arsyad (2008) berpendapat bahwa konsep interaktif paling erat kaitannya dengan media berbasis komputer, interaksi dalam lingkungan pembelajaran berbasis komputer umumnya mengikuti tiga unsur yaitu: 1) urut-urutan instruksional yang dapat diurutkan, 2) jawaban/respon atau pekerjaan siswa dan 3) umpan balik yang dapat disesuaikan. Media interaktif biasanya mengacu pada produk dan layanan pada sistem berbasis komputer digital yang merespontindakan pengguna dengan menyajikan konten seperti teks, grafik, animasi, video, audio, dan lain-lain.

Camtasia studio merupakan perangkat lunak (software) yang dikembangkan oleh TechSmith Coorporation khusus bidang multimedia. Camtasia Studio adalah program aplikasi yang dikemas untuk recording, editing, dan publishing dalam membuat video presentasi yang ada pada layar (screen) komputer. Camtasia studio adalah software untuk meng capture tampilan layer monitor, dengan ditambahi audio dan video, bisa juga kita gunakan untuk merekam hasil presentasi powerpoint ke dalam format video. Camtasia Studio dapat membantu dan melatih kita dalam menyampaikan serta berinteraksi dengan audiens. Camtasia Studio memiliki kemampuan untuk merekam suara yang ada dalam layar,termasuk kegiatan di desktop, presentasi powerpoint, narasi suara, dan webcam video. Camtasia Studio adalah salah satu solusi lengkap untuk menciptakan video propesional dan aktivitas desktop PC dengan cepat. Siapapun dapat merekam dan menciptakan satu pelajaran penuh video gerak atau presentasi.

Video tutorial merupakan panduan tentang cara menjelaskan sesuatu, baik materi pembelajaran atau pelatihan (training) maupun proses pengoprasian suatu sistem (hardware dan sofeware) yang dikemas dalam bentuk video. Format sajian ini merupakan multimedia pembelajaran yang dalam penyampaian materinya dilakukan secara tutorial, sebagaimana layaknya tutorial yang dilakukan oleh guru atau instruktur. Informasi yang berisi suatu konsep disajikan dengan teks, gambar, baik diam atau bergerak dan grafik. Pada saat yang tepat, yaitu ketika dianggap bahwa pengguna telah membaca menginterprestasikan dan menyerap konsep itu, diajukan serangkaian dan tugas. Jika jawaban atau respon siswa benar, kemudian dilanjutkan dengan materi berikutnya. jika jawaban atau respon siswa salah, maka siswa harus mengulang memahami konsep tersebut secara keseluruhan ataupun pada bagianbagian tertentu saja (remedial). Kemudian pada bagian akhir biasanya akan diberikan serangkaian pertanyaan yang untuk mengukur tingkat pemahaman siswa atas konsep atau materi yang disampaikan. Tutorial atau tutoring adalah bantuan atau bimbingan belajar yang bersifat akademik oleh tutor kepada siswa untuk membantu kelancaran proses belajar madiri siswa secara perorangan atau kelompok berkaitan dengan materi ajar. Tutorial dilaksanakan secara tatap muka atau jarak jauh berdasarkan konsep belajar mandiri. Konsep 
belajar mandiri dalam tutorial mengandung pengertian, bahwa tutorial merupakan bantuan belajar dalam upaya memicu dan memacu kemandirian, disiplin, dan inisiatif diri siswa dalam belajar dengan minimalisasi intervensi dari pihak pembelajar yang dikenal sebagai tutor. Prinsip pokok tutorial adalah "kemandirian siswa". Tutorial tidak ada, jika kemandirian tidak ada. Jika siswa tidak belajar di rumah, dan datang ke tutorial dengan "kepala kosong', maka yang terjadi adalah "pembelajaran" biasa, bukan tutorial. Jadi video tutorial adalah salah satu media pembelajaran yang berfungsi untuk melakukan pertukaran informasi antara pengirim dan penerima sehingga tercapainya suatu tujuan yang dikehendaki.

Mata pelajaran pemrograman web Pemrograman web disini diambil dari 2 suku kata yaitu pemrograman dan web. Pemrograman diartikan proses, cara, perbuatan program definisi Web jaringan komputer yang terdiri dari kumpulan situs internet yang menawarkan teks dan grafik dan suara dan sumber daya animasi melalui protokol transfer hypertext. Orang banyak mengenal web dengan istilah WWW (world wide web), World Wide Web adalah layanan internet yang paling populer saat ini internet mulai dikenal dan digunakan secara luas setelah adanya layanan WWW. WWW adalah halaman-halaman website yang dapat saling terkoneksi satu dengan lainnya (hyperlink) yang membentuk samudra belantara informasi. WWW berjalan dengan protokol HyperText Transfer Protokol (HTTP). Halaman web merupakan file teks murni (plain text) yang berisi sintaks-sintaks HTML yang dapat dibuka/ dilihat/ diterjemahkan dengan internet browser. Sintaks HTML mampu memuat konten text, gambar, audio, video dan animasi. Kini internet identik dengan web, karena kepopuleran web sebagai standar interface pada lanyanan-layanan yang ada di internet, dari awalnya sebagai penyedia informasi, ini digunakan juga untuk komunikasi dari email sampai dengan chatting, sampai dengan melakukan transaksi bisnis (commerce).

Berdasarkan rumusan masalah dan tujuan penelitian, jenis penelitian pengembangan media pembelajaran berbasis camtasia studio video CD interaktif multimedia untuk mata pelajaran pemprograman web di smk negeri 3 singaraja yang peneliti gunakan adalah penelitian pengembangan (research and development) yaitu penelitiaan yang bertujuan untuk mengembangkan, memperluas, dan menggali lebih dalam teori dari suatu ilmu pengetahuan tertentu. Menurut Sugiyono (2009), langkah-langkah penelitian R \& D terdiri dari 10 langkah sebagai berikut: (1) potensi dan masalah, (2) pengumpulan data, (3) desain produk, (4) validasi desain, (5) revisi desain, (6) ujicobaproduk, (7) revisi produk, (8) ujicoba pemakaian, (9) revisi produk, dan (10) produksi masal. Namun pada penelitian ini hingga langkah ke lima.

Menurut Sugiyono (2015:409) "Penelitian ini berangkat dari adanya potensi dan masalah". Potensi adalah segala sesuatu yang bila didayagunakan akan memiliki nilai tambah. Masalah juga bisa dijadikan sebagai potensi, apabila dapat mendayagunakannya. Berdasarkan hasil observasi, pada Jurusan Multimedia di SMK Negeri 3 Singaraja memiliki referensi yang banyak dalam menunjang proses belajar mengajar di kelas, namun isi referensi yang digunakan masih menggunakan software lama serta masih dalam bentuk fisik sehingga membutuhkan tempat dan ruang yang banyak. Kurangnya siswa dalam memiliki referensi tersebut dalam menunjang proses belajar mereka serta kemauan siswa untuk membaca referensi sangatlah kurang. Dari potensi dan masalah yang ditemukan, maka dicoba untuk mengembangkan sebuah media pembelajaran berbasis video cd interaktif multimedia dalam mata pelajaran Jurusan Multimedia sebagai referensi yang didalamnya terdapat tahap-tahap pembuatan html dengan cepat dan mudah dimengerti. Sebelum mendesain produk, perlu diadakan proses pengumpulan data. Pada tahap ini pengumpulan data dilalukan dengan melakukan wawancara kepada siswa dan guru terkait mata pelajaran yang terdapat dalam Jurusan Multimedia sehingga produk yang dihasilkan sesuai dengan kebutuhan. Produk yang dihasilkan pada penelitian ini yaitu berupa video cd interaktif multimedia dengan tamplian video didalamnya yang nantinya dapat menarik siswa untuk ingin membaca serta mempelajari mata pelajaran pemrograman web di Jurusan Multimedia. Dalam desain produk video cd interaktif.

Pada tahap ini, hasil rancangan produk video cd interaktif dalam mata pelajaran penrograman web di Jurusan Multimedia dilakukan uji validasi. Uji validasi dilakukan oleh orang-orang yang memiliki pengetahuan, pengalaman, dan pemahaman dalam materi tersebut. Validator tersebut adalah dosen ahli dalam bidang media dan materi, serta guru pengampu mata pelajaran pemrograman web pada Jurusan Multimedia SMK Negeri 3 Singaraja. 
Setelah hasil produk video cd interaktif multimedia divalidasi, hasil validasi kemudian didiskusikan dengan validator. Apabila hasil validasi video $\mathrm{cd}$ interaktif multimedia memperoleh hasil yang kurang memuaskan dari validator, maka produk tersebut dilakukan penyempurnaan hingga hasil validasi meningkat. Apabila hasil validasi memperoleh hasil yang memuaskan dari validator, maka dilanjutkan dengan uji coba produk.

Produk yang telah divalidasikan oleh ahli kemudian diujicobakan pada siswa. Uji coba produk dilakukan dengan melakukan uji perorangan, uji coba kelompok kecil, dan uji coba lapangan. Data yang diperoleh kemudian dianalisis dan digunakan untuk memperbaiki atau merevisi produk yang dikembangkan. Pada uji coba lapangan dilakukan dengan memperhatikan ketertarikan siswa dalam melihat dan memahami isi dari validasi video cd interaktif multimedia, selanjutnya angket atau kuisioner diberikan kepada siswa untuk menilai validasi video cd interaktif multimedia yang digunakan. Dari hasil penilaian angket siswa tersebut akan dianalisis sehingga terlihat bahwa validasi video cd interaktif multimedia layak atau tidaknya sebagai bahan referensi atau media pembelajaran

Subjek dalam penelitian ini adalah media pembelajaran dalam bentuk perangkat lunak berupa video cd interaktif multimedia dengan menggunakan video yang kelak akan digunakan sebagai referensi atau media pembelajaran oleh guru dan siswa Jurusan Multimedia di SMK Negeri 3 Singaraja. Menurut Sugiyono (2015:148) "Instrumen penelitian adalah suatu alat yang digunakan untuk mengukur fenomena alam maupun sosial yang diamati". Untuk mengetahui kelayakan video cd interaktif multimedia yang telah dibuat untuk referensi atau media pembelajaran, maka digunakan instrumen berupa angket yang diberikan kepada ahli media dan ahli materi. Instrumen-instrumen yang digunakan untuk mengukur tingkat kelayakan video cd interaktif multimedia untuk validasi ahli yang telah dibuat sebagai berikut.

Validasi Media pembelajaran berbasis camtasia studio cd interaktif dilakukan oleh validator materi dan validator media pembelajaran yang dianalisis menggunakan teknik deskriptif presentase dengan rumus. (Sudijono dalam Perdana, 2013:25):

$$
P=\frac{f}{N} \times 100 \%
$$

Keterangan:

$\mathrm{P}=$ presentase skor

f $=$ jumlah skor yang diperoleh

$\mathrm{N}=$ jumlah skor maksimum

Validator materi dan media akan menjawab pertanyaan dengan memberi skor sesuai rubrik validasi (skor tertinggi=1 dan skor terendah=0). Hal ini bertujuan untuk mendapatkan jawaban yang tegas terhadap suatu permasalahan yang ditanyakan. (Sugiyono, 2015).

Penentuan kriteria validitas ditentukan dengan cara sebagai ,menentukan persentase skor ideal (skor maksimum), yaitu $(1: 1) \times 100 \%=100 \%$, menentukan persentase skor terendah (skor minimum),yaitu $(0: 1) \times 100 \%=0 \%$, menentukan range, yaitu $100 \%-0 \%=100 \%$, Menetapkan kelas interval, yaitu $=2$ (setuju, tidak tidak setuju), Menentukan panjang interval, yaitu $100: 2=50 \%$. Berdasarkan perhitungan di atas, maka rentang persentase dan criteria.

Tabel 1. Rentang persentase dan kriteria kualitatif uji kelayakan media

\begin{tabular}{cc}
\hline Rentang Persentase $(\%)$ & Kriteria Kualitatif \\
\hline $50 \%-100 \%$ & Layak \\
\hline $0 \%-49 \%$ & Tidak Layak \\
\hline
\end{tabular}

Perencanaan desain produk merupakan gambaran awal dari video cd Intraktif multimedia yang akan dibuat. video cd Intraktif multimedia merupakan tutorial berbasis video digital yang 
digunakan sebagai referensi baik oleh guru maupun oleh siswa. Berikut ini desain dari tampilan video cd Intraktif multimedia.

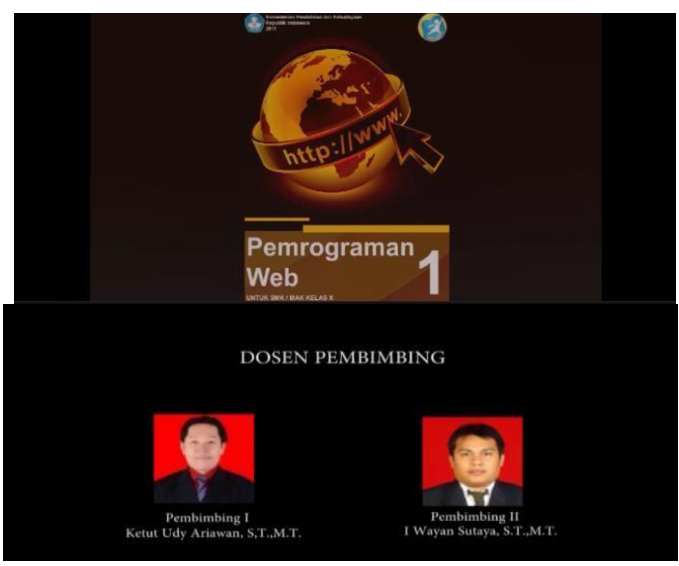

Gambar 1. Tampilan cover bab pada mata pelajaran pemrograman web

Berikut ini desain dan tampilan bab dari video cd Intraktif multimedia pemrograman web.

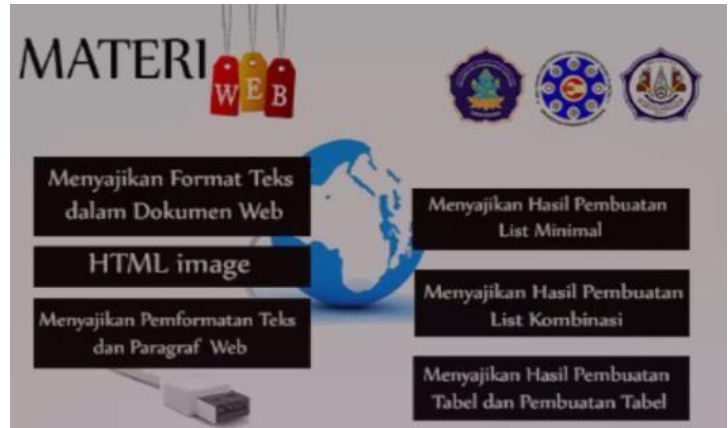

Gambar 2. Tampilan awal bab pada mata pelajaran pemrograman web

Berikut tahap pembuatan tutorial video serta memasukan materi pemrograman web dengan menggunakan camtasia studio 5.

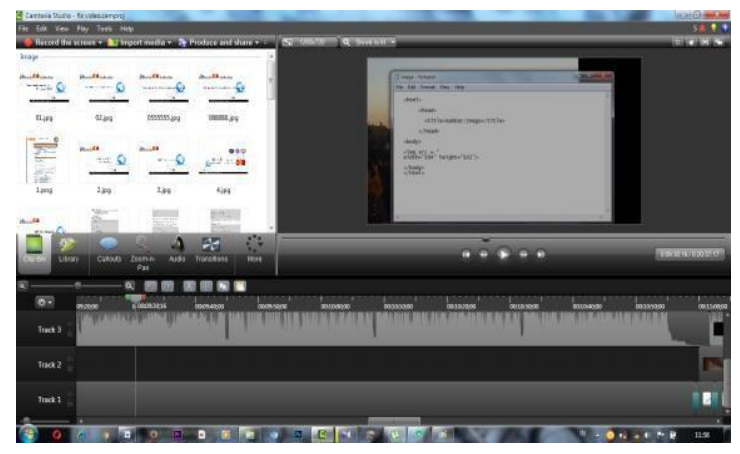

Gambar 3. Pembuatan template pada Camtasia studio 5

Untuk dapat menghasilkan produk tertentu digunakan penelitian yang bersifat analisis kebutuhan dan untuk mengkaji keefektifan produk tersebut supaya dapat diterima di masyarakat luas, maka diperlukan penelitian untuk mnguji keefektifan produk tersebut. Produk hasil pengembangan yang telah selesai dibuat berupa media pembelajaran menggunakan software camtasia kemudian dilakukan uji coba kepada responden atau orang lain. Objek pada penelitian ini adalah video cd Intraktif multimedia interaktif multimedia sebagai bahan referensi atau media pembelajaran untuk guru dan siswa. 
Berdasarkan hasil penelitian dan pembahasan yang telah diuraikan, maka dari pengembangan media pembelajaran berbasis camtasia studio video interaktif multimedia untuk mata pelajaran pemrograman web di SMK negeri 3 singaraja, dapat digunakan sebagai media pembelajaran yang sesuai. Pada media video cd interaktif mengunakan perbantuan dengan aplikasi. dalam pengabungan materi gambar,video,suara mengunkan perbantuan aplikasi camtasia, membuat efex yang di sisipkan di video intraktif mengunakan perbantuan aplikasi adobepremire dan pengeditan gambar tidak bergerak mengunakan perbantuan aplikasi adobephotoshop. Hasil dari mengembangkan media video cd interaktif multimedia pada mata pelajaran pemrograman web. Telah sesuai dengan indikator silabus

\section{DAFTAR PUSTAKA}

Arsyad, Azhar. 1997. Media Pembelajaran. Jakarta: PT. Raja Grafindo Persada.

Lestari, Dewi. 2012. Definisi Multimedia. Artikel Multimdia. Sukabumi: Universitas Muhammadiyah Sukabumi.

Imam Mu'adin. 2009. Pengembangan Media Pembelajaran Berbasis Komputer Untuk Mata Pelajaran PKn SMP. Thesis.

Ahmadi, Abu dkk. 2001. Ilmu Pendidikan. Edisi 2. Jakarta: PT. Rineka Cipta

Arsyhar, Rayandra. 2012. Media Pembelajaran. Edisi 1. Jakarta:Referensi Jakarta Arif Sadiman., dkk. 2003. Media Pendidikan (Pengertian Pengembangan dan Pemafaatannya). Jakarta: CV Rajawali.

Asyar,Rayandra 2012. Kreatif Mengembangkan Media Pembelajaran. Jakarta: Refrensi Jakrata. 